\title{
Sentinel Ganglion
}

\author{
Carlos Álvarez Laso*11, Jonás García ${ }^{1}$, Enedina Azcano González ${ }^{1}$, Valentina Sosa Rodríguez ${ }^{1}$, Diana \\ Rodríguez Rodríguez ${ }^{2}$ and Raúl Rodríguez Aguilar ${ }^{2}$ \\ ${ }^{1}$ Department of Surgery, Hospital de Cabueñes, Gijon, Spain \\ ${ }^{2}$ Department of Pathology, spian Hospital de Cabueñes, Gijon, Spain
}

*Corresponding author: Carlos Álvarez Laso PhD, Department of Surgery, Hospital de Cabueñes,Gijon, Spain

$\begin{array}{ll}\text { ARTICLE INFO } & \text { ABSTRACT } \\ \begin{array}{l}\text { Received: } \\ \text { Published: March 13, } 2019\end{array} & \begin{array}{r}\text { Sentinel lymph node technique is well known among physicians who treat breast } \\ \text { cancer or melanoma but is roll in colorectal cancer is still under investigations. We made } \\ \text { an analysis of this simple technique that could be applied is order to make a more precise } \\ \text { stadification of colon cancer. }\end{array}\end{array}$

García, Enedina Azcano González

Valentina Sosa Rodríguez, Diana

Rodríguez Rodríguez, Raúl Rodríguez

Aguilar. Sentinel Ganglion. Biomed

J Sci \& Tech Res 16(2)-2019. BJSTR.

MS.ID.002823.

\section{Objectives}

To start in our hospital the sentinel node detection technique in colon tumors, using a blue methylene tint technique, in the operating room, once the specimen is removed from the patient as was well described by Sardon et al. [1,2]. The purpose of this technique is to raise the sensitivity in the diagnostic of lymph node metastasis in colon cancer, by performing intensive studies in the sentinel nodes.

\section{Methods}

Consecutive colon cancer patients, candidates for surgical treatment were selected. The final sample was made of 43 patients. In the course of surgery once the specimen is removed, the exvivo blue methylene technique is performed. The blue methylene is injected into the tumour, using a total volume of $2 \mathrm{~mL}$. The specimen is not opened. Thereupon the tumour is massaged for five minutes. Afterwards the sentinel nodes, now dyed, are sought in the mesocolon and then removed. The extracted lymph nodes are subjected to the OSNA (One Step Nucleic acid Amplification) technique, which has a high sensitivity in the detection of lymph node metastasis. This amplification method is being able to identify copies of RNAm of the cytokeratin CK19, which is plentiful in tumour cells but absent in normal lymph nodes. For the rest of the lymph nodes in the specimen, conventional histopathological work up was performed.

\section{Results}

The sentinel node was positive for metastasis in 6 cases, in which only one of them the conventional studies were negative. The sentinel node was negative in 37 cases, in 7 of these cases the conventional histopathological workup detected metastasis. As a result of that, a sensitivity of $42 \%$ and a specificity of $96 \%$ is concluded for our sample. The positive predictive value is $83 \%$ and predictive negative is $81 \%$ in our sample.

\section{Discussion}

Although sentinel lymph node technique is well known among surgeons and pathologist since 1960 [3] , its application in colon cancer remains controversial. The lymphatic drainage mapping in colon cancer is not defined, even more some authors think that is impossible to define it [4]. Our research ended up with very poor results trying to determine the first stage of drainage. We could not reproduce the results of other authors. 


\section{Conclusion}

The tested technique is simple and it's possible to carry out with it in any coloproctology unit, if OSNA procedure is available at the Pathology department. The achieved results are insufficient to conclude the usefulness of this technique.

\section{References}

1. Edwin S van der Zaag, Wim H Bouma, Pieter J Tanis, Dirk T Ubbink, Willem A Bemelman, et al. (2012) Systematic review of sentinel lymph node mapping procedure in colorectal cancer. Ann Surg Oncol 19(11): 3449-3459.

\section{ISSN: 2574-1241}

DOI: 10.26717/BJSTR.2019.16.002823

Carlos Álvarez Laso. Biomed J Sci \& Tech Res

(C) (i) This work is licensed under Creative

Submission Link: https://biomedres.us/submit-manuscript.php
2. José Domingo Sardón Ramos, José Errasti Alustiza, Eugenia Campo Cimarras, Baltasar Cermen, José Antonio Romero Martínez, et al. (2013) Sentinel lymph node technique in colon cancer. Experience in 125 cases. Cir ESP 91(6): 366-371.

3. Ernest A Gould, Theodore Winship, Philip H Philbin, Harry Hyland Kerr (1960) Observations of a sentinel Lymph node in cancer of the parotid. Cancer 13(1): 77-78.

4. Saha, Dan AG, Bernan B, Wiese D, Schochet E, et al. (2004) Lymphazurin $1 \%$ vs $99 \mathrm{~m}$ Tc sulfur colloid for lymphatic mapping in colorectal tumors: a comparative analysis. Ann Surg Oncol 11(1): 21-26.

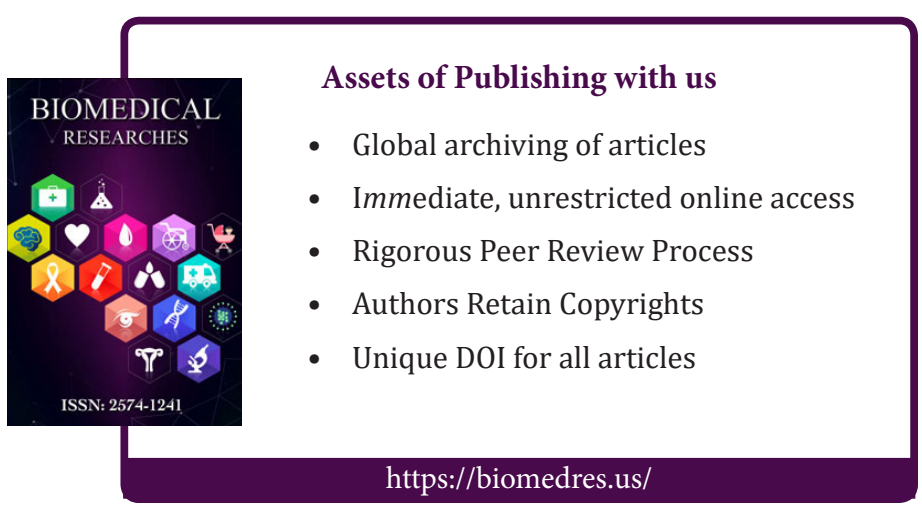

